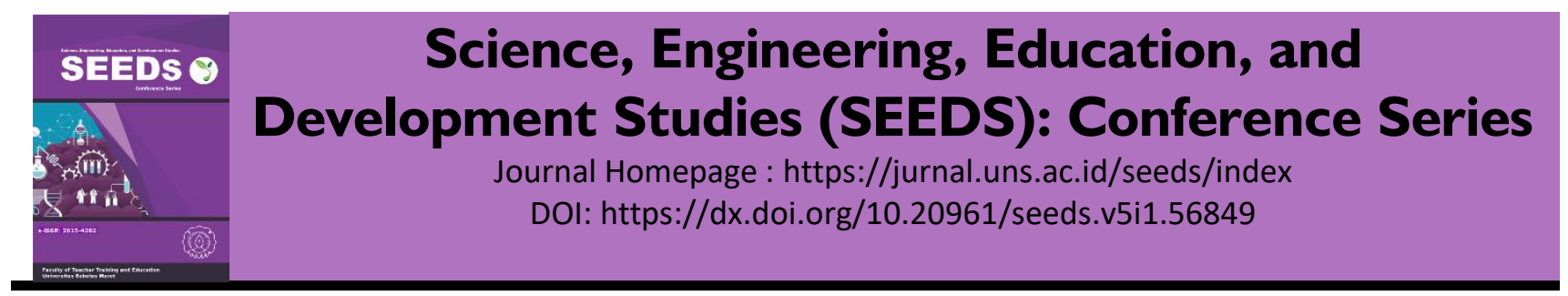

\title{
PENINGKATAN KETERAMPILAN PRAKTIKUM GERBANG LOGIKA DI MATA PELAJARAN SISTEM KOMPUTER MENGGUNAKAN APLIKASI LOGIC CIRCUIT DESIGNER (LCD) ADA KELAS X TKJ SMKN 1 KETAPANG
}

Arie Sumartini

SMK Negeri 1 Ketapang

arie.smkn1.ktg@gmail.com

Artikel Info :

Available online 01/03/2021

Kata Kunci:

computer system

logic circuit designer
Abstrak

The limitations of practice in the department become a dilemma in assessing students Computer Systems course in the Department of Computer and Network Engineering class X. Meanwhile In the realm of assessment there are values or skills. use Application Logic Circuit Designer (LCD) is one of the existing solutions. This app too can be installed (installed) on a Laptop or Personal Computer (PC). Whatever the purpose The use of this application in this research is so that students are able to carry out practicum in accordance with the material presented and develop skills without limit. To be able to increase the motivation of student learning outcomes on the Gate material Class $X$ Logic majoring in Computer and Network Engineering (TKJ) at SMK Negeri 1 Ketapang. This research is a classroom action research consisting of 2 cycles, with the help of learning participation observation sheet from 36 students. Each cycle consists of planning, implementation, observation and reflection. results Based on research obtained from the use of Logic Circuit Designer (LCD) applications in learning must follow these steps that has been determined, namely starting from downloading the application, installing the application on a laptop or smartphone until how to use it. 


\section{PENDAHULUAN}

Seorang pendidik dituntut harus bisa menguasai teknologi sebab teknologi bisa dijadikan salah satu alat untuk memudahkan dalam proses belajar mengajar di kelas. Dalam proses pembelajaran di kelas tidak dapat berdiri sendiri. Hal ini dikarenakan pembelajaran mengandung beberapa komponen yang saling berkaitan satu sama lain agar dapat mencapai tujuan pembelajaran yang telah ditentukan. Komponen-komponen tersebut yaitu tujuan, materi, metode, media dan evaluasi. Apabila salah satu komponen tersebut tidak terpenuhi, maka tujuan pembelajaran tidak akan tercapai secara maksimal (Sumantri \& Permana 2001).

Dewasa ini aplikasi pendidikan berkembang pesat. Tidak salah jika pengajar melirik menggunakan aplikasi yang ada sebagai media pembelajaran. Apalagi jika aplikasi tersebut gratis dan tidak sulit mengoperasikannya. Selama tidak menggunakan aplikasi peserta didik hanya menggunakan dan menganalisa tugas secara manual. Dalam arti hanya menggunakan gambar manual dimana pembuktiannya terkadang banyak yang salah. Disini peneliti mulai berfikir bagaimana pembelajaran produktif juga bisa di lakukan dengan memanfaatkan perangkat lunak dan ini adalah salah satu alasan peneliti untuk mencoba menggunakan media perangkat lunak ini dalam pelajaran. Sehingga seakan-akan pembelajaran telah masuk ke dunia mereka yang selama ini mereka jalani. Media pembelajaran berbentuk perangkat lunak yakni Logic Circuit Designer (LCD) (Asyhar, 2011). Bicara masalah nilai hasil belajar peserta didik kelas X, juga memiliki nilai belajar yang masih sangat rendah.

Berdasarkan hal-hal yang telah diuraikan di atas, maka diadakan penelitian yang berjudul "Peningkatan Keterampilan Praktikum Gerbang Logika Di Mata Pelajaran Sistem Komputer Menggunakan Aplikasi Logic Circuit Designer (LCD) Pada Kelas X TKJ SMKN 1 Ketapang” penelitian ini diharapkan dapat meningkatkan keterampilan praktikum peserta didik dalam pelajaran Sistem Komputer.

Pada penelitian kali ini peneliti akan meneliti tentang bagaimanakah langkah-langkah penggunaan aplikasi Logic Circuit Designer (LCD) dalam dalam materi Gerbang Logika Kelas X TKJ pada SMK Negeri 1 Ketapang, bagaimanakah peningkatan keterampilan praktikum peserta didik pada materi Gerbang Logika Kelas X TKJ pada SMK Negeri 1 Ketapang, dan bagaimanakah peningkatan nilai keterampilan peserta didik pada materi Gerbang Logika Kelas X TKJ pada SMK Negeri 1 Ketapang.

\section{METODE}

Subjek penelitian tindakan kelas adalah peserta didik kelas X TKJ 1 berjumlah 36 terdiri dari 9 orang siswi perempuan dan 27 siswa laki- laki.Dilaksanakan di kelas X pada tahun pelajaran 2018/2019 selama satu semester, dimulai bulan Agustus. Karna dalam tugas peneliti hanya mencakup 1 kelas ini saja. Metode penelitian yang digunakan ialah penelitian tindakan kelas, dimana peneliti ingin menggambarkan atau melukiskan fakta-fakta atau keadaan yang terlihat tentang meningkatnya semangat motivasi belajar peserta didik dalam materi Gerbang Logika. Berikut ini alur model penelitiannya:

a. Perencanaan

Mencari informasi apakah ada kemungkinan pembelian alat praktik mata pelajaran ini, merencanakan pembelajaran dengan membuat modul praktikum, dan mempersiapkan aplikasi Logic Circuit Disigner (LCD) dengan cara memasang aplikasi ini di PC atau Laptop disekolah dan di Laptop milik siswa.

b. Pelaksanaan/Implementasi Tindakan

Pada tahap ini dilaksanakan proses praktikum dilaboratorium dan dikelas. Praktikum dilaksanakan sesuai dengan rencana yang telah disusun. Pelaksanaan tindakan dilaksanakan selama 2 jam pelajaran $\mathrm{x} 45$ menit untuk 2 kali pertemuan ( 2 x 45 menit). Pertemuan pertama digunakan untuk proses pemasangan perangkat lunak di PC atau Laptop, setelah pemasangan selesai guru memberikan contoh pengerjaan soal dan fungsifungsi dari setiap tombol yang ada di perangkat lunak.

c. Pengamatan (Observasi)

Observasi terhadap proses praktikum dengan menggunaan perangkat lunak LCD, mengamati langsung peningkatan motivasi belajar peserta didik, dan mengamati aktivitas siswa pada proses praktikum, yang bertujuan untuk mengetahui pertumbuhan sikap.

d. Refleksi

Melakukan evaluasi dan mengolah data hasil observasi dari kegiatan perbaikan praktikum yag telah dilakukan. Hasil evaluasi dibandingkan dengan indikator kinerja yang telah dilakukan. Jika hasil evaluasi menunjukkan kecukupan dan sesuai dengan indikator kinerja, maka penelitian tindakan dicukupkan dan selesai. 


\section{HASIL DAN PEMBAHASAN}

\section{A. Hasil}

Hasil penelitian diuraikan dalam bentuk tahapan yang terdiri dari siklus-siklus pembelajaran yang dilakukan dalam proses belajar mengajar di dalam kelas.

Dari hasil pelaksanaan siklus 1 praktikum dengan tidak menggunakan perangkat lunak LCD dengan materi gerbang logika mata pelajaran sistem komputer di kelas X TKJ 1 dan X TKJ 2 diperoleh hasil penilaian tes hasil belajar yang telah dilakukan. Berikut ini merupakan hasil dari rekapitulasi penilaian hasil belajar peserta didik dengan tanpa menggunakan perangkat lunak LCD pada siklus 1:

Tabel 1. Hasil Rekapitulasi Penilaian Hasil Belajar Silus 1 Dengan Tidak Menggunakan Perangkat Lunak LCD

\begin{tabular}{clc}
\hline No & \multicolumn{1}{c}{ Uraian } & Hasil Peserta Didik \\
\hline 1 & Nilai rata-rata & 57 \\
2 & Nilai tertinggi & 80 \\
3 & Nilai terendah & 20 \\
4 & Jumlah peserta didik yang tuntas & 10 \\
5 & Jumlah peserta didik yang tidak tuntas & 26 \\
6 & Prosentase ketuntasan & $28 \%$
\end{tabular}

Berdasarkan penelitian di siklus 1, sudah dapat diketahui di atas ketuntasan hasil belajar peserta didik masih jauh dari KKM yakni 80. Nilai rata-rata yang didapat pada siklus 1 adalah 57, peserta didik yang tuntas hanya 10 Orang dari 36 orang peserta didik dan yang tidak tuntas berjumlah 26 orang, sehingga prosesntase peserta didik yang tuntas adalah sebesar $28 \%$.

Dari hasil penelitian data yang diperoleh di atas dapat diketahui pada hasil observasi kegiatan guru diperoleh prosentase sebesar $70 \%$. Sedangkan pada penilaian untuk kerja kegiatan peserta didik diperoleh prosentase sebesar $28 \%$. Kriteria keberhasilan penelitian ini masih perlu ditingkatkan karena masih termasuk dalam kategori buruk.

Langkah yang akan dilakukan oleh peneliti yaitu akan memberikan tambahan poin bagi mereka yang bisa mengerjakan soal yang akan diberikan oleh peneliti sehingga peserta didik bisa lebih aktif selama proses pembelajaran berlangsung. Oleh karena itu akan dilakukan penelitian pada siklus berikutnya siklus 2 .

Pada refleksi siklus 2 ini, akan dikaji apa yang telah dilaksanakan dengan baik maupun yang masih kurang baik selama proses praktikum dengan menggunakan perangkat lunak LCD.

Dari hasil pelaksanaan siklus 2 pembelajaran dengan menggunakan perangkat lunak LCD dengan materi gerbang logika mata pelajaran system komputer di kelas X TKJ SMKN 1 Ketapang diperoleh hasil penilaian tes hasil belajar yang telah dilakukan. Berikut ini merupakan hasil dari rekapitulasi penilaian hasil belajar peserta didik dengan menggunakan perangkat lunak LCD pada siklus 2:

Tabel 2. Hasil Rekapitulasi Penilaian Hasil Belajar Silus 2 Dengan Menggunakan Perangkat Lunak LCD

\begin{tabular}{clc}
\hline No & \multicolumn{1}{c}{ Uraian } & Hasil Peserta Didik \\
\hline 1 & Nilai rata-rata & 89 \\
2 & Nilai tertinggi & 90 \\
3 & Nilai terendah & 70 \\
4 & Jumlah peserta didik yang tuntas & 32 \\
5 & Jumlah peserta didik yang tidak tuntas & 4 \\
6 & Prosentase ketuntasan & $89 \%$ \\
\hline
\end{tabular}


Dari data di atas dapat diketahui bahwa praktikum dengan menggunakan pernagkat lunak LCD pada materi gerbang logika mata pelajaran system komputer di kelas X TKJ SMKN 1 Ketapang pada siklus 2 diperoleh nilai rata-rata peserta didik yaitu 89\&. Dari 36 peserta didik, sebanyak 4 peserta didik yang tidak tuntas karena nilai yang diperoleh belum mencapai KKM yang di tetapkan. Nilai KKM yang ditetapkan oleh sekolah yaitu 80. Prosentase ketuntasan peserta didik pada siklus 2 ini diperoleh sebesar $89 \%$, hal ini sudah menunjukkan bahwa sudah tercapai dari kriteria yang telah diharapkan, karena sudah mencapai KKM yang telah ditetapkan sekolah.

Dari prosentase hasil selama proses belajar mengajar, peneliti telah melaksanakan semua pembelajaran dengan sangat baik. Prosentase pelaksanaannya untuk masing-masing aspek sudah mencapai kriteria baik yaitu $96 \%$ pada siklus 2 lebih baik dari siklus 1 dengan prosentase $70 \%$. Kemudian berdasarkan data hasil pengamatan diketahui bahwa peserta didik aktif selama proses belajar berlangsung dan kekurangan pada siklus sebelumnya sudah mengalami perbaikan dan peningkatan sehingga mencapai sangat baik dengan perolehan prosentase pada siklus 2 yaitu $89 \%$ lebih baik dari pada siklus 1 yaitu $28 \%$.

Dari data di atas menunjukkan nilai rata-rata kelas pada siklus 2 sebesar 82 lebih besar dari siklus 1 yang hanya 57 dan juga prosentase ketuntasan belajar peserta didik sebesar $89 \%$ lebih besar dari siklus 1 yang hanya $28 \%$, hal ini dapat diketahui dari hasil nilai tiap peserta didik mengalami ketuntasan sesuai dengan KKM yang telah ditentukan yaitu 80, jadi penelitian yang dilakukan pada siklus 2 ini mengalami keberhasilan.

\section{B. Pembahasan}

Pada Penelitian Tindakan Kelas (PTK) ini merupakan upaya guru, untuk meningkatkan mutu pembelajarannya di elas yang dikelolanya, dengan tujuan meningkatkan ketrampilan praktikum peserta didik dengan menggunakan perangkat lunak LCD dikelas X TKJ SMKN 1 Ketapang.

\section{Langkah-langkah penggunaan perangkat lunak LCD pada materi gerbang logika kelas $\mathrm{X}$ TKJ SMKN 1 Ketapang}

Dalam pembahasan tentang langkah-langkah penggunaan perangkat lunak LCD memiliki langkah sebagai berikut:

a. Pemasangan Perangkat Lunak

Tahap awal guru memberikan alat dimana perangkat lunak ini bias diunduh. Kemudian peserta didik akan melakukan pemasangan perangkat lunak ini di pc atau laptop. Saat pemasangan mungkin ada beberapa file system yang belum terinstal sempurna akan tepasang secara otomatis.

Setelah perangkat lunak dipasang maka guru akan menjelaskan penngunaan perangkat lunak ini.

\section{Hasil penelitian tentang peningkatan keterampilan menggunakan perangkat lunak LCD}

Berikut ini adalah grafik hasil pengamatan menggunakan perangkat lunak LCD dan penilaian menggunakan lembar observasi oleh observer.

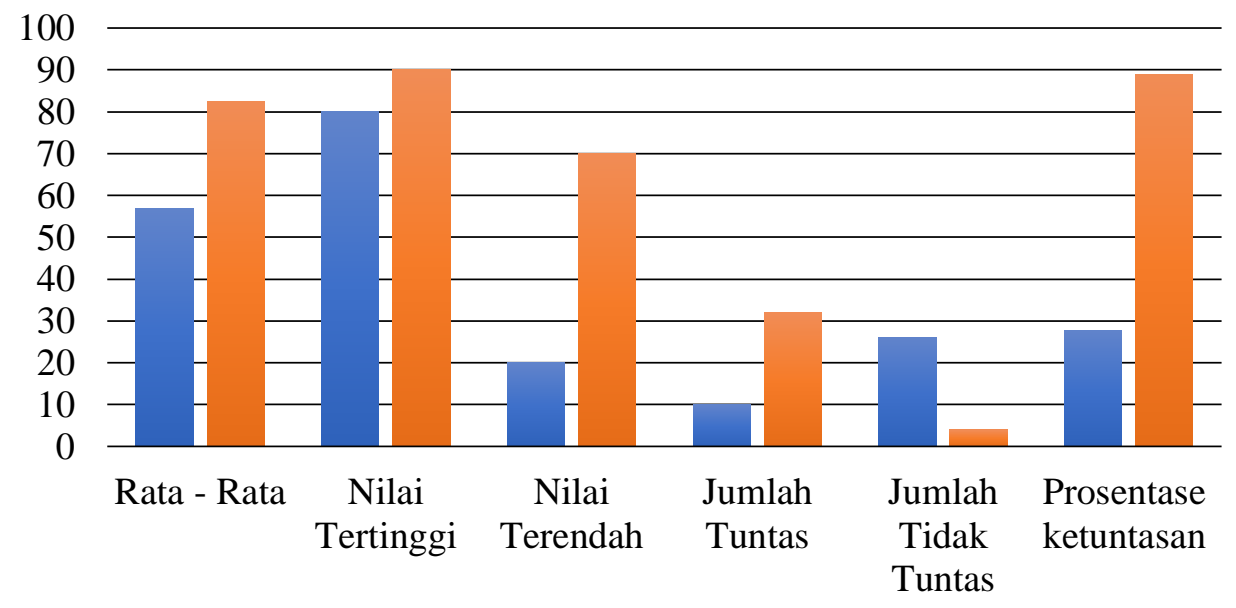

- Siklus 1 - Siklus 2

Diagram 1 Menggunakan Lembar Penilaian Unjuk Kerja 
Berdasarkan hasil pengamatan pelaksanaan observasi peserta didik pada siklus 1 dalam penerapan pembelajaran dengan tidak menggunakan perangkat lunak LCD di kelas X TKJ SMKN 1 Ketapang ini masih banyak peserta didik kurang kosentrasi sehingga peserta didik kurang bisa menjawab pertanyaanpertanyaan dan soal yang diberikan oleh peneliti dan kurang aktif dalam aktifitas di dalam kelas, hal ini dapat dilihat dari aktifitas peserta didik yang memperoleh prosentase $28 \%$ sehingga hal ini mempengaruhi hasil belajar peserta didik.

\section{Hasil penelitian tentang hasil belajar dengan menggunakan perangkat lunak LCD di Kelas X TKJ SMKN 1 Ketapang}

Dalam pembahasan hasil penelitian tentang pelaksanaan pembelajaran terdapat dua hasil pengamatan yang dilakukan yakni pengamatan pelaksanaan observasi guru dan hasil belajar peserta didik dengan menggunakan perangkat lunak LCD.

a. Pengamatan pelaksanaan observasi guru

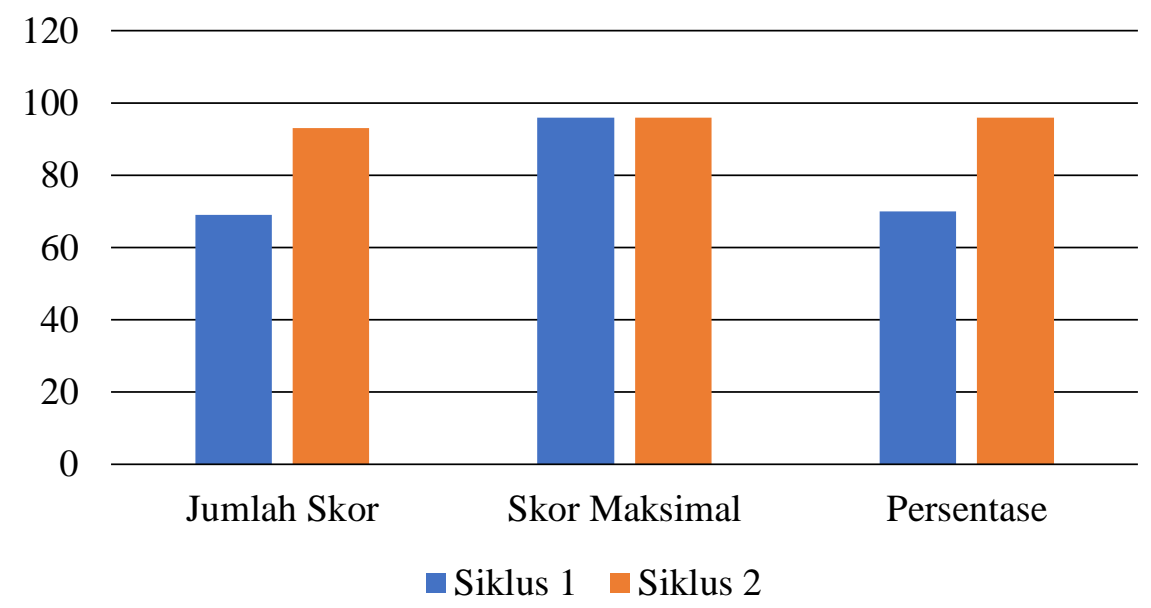

Diagram 2 Pengamatan Lembar Observasi Aktivitas Guru

Berdasarkan hasil pengamatan pelaksanaan observasi guru pada siklus 1 menunjukkan bahwa praktikum dengan tidak menggunakan perangkat lunak LCD kurang maksimal karena prosentase yang diperoleh $28 \%$. Pada siklus 2 kinerja guru telah diperbaiki. Guru bertindak secara maksimal dalam menggunakan aplikasi sehingga mendorong peserta didik untuk aktif dalam pembelajaran dan di buktikan dengan meningkatnya prosentase ketuntasan menjadi $89 \%$ lebih baik dari pada siklus 1 .

b. Hasil belajar peserta didik dengan menggunakan aplikasi Plickers

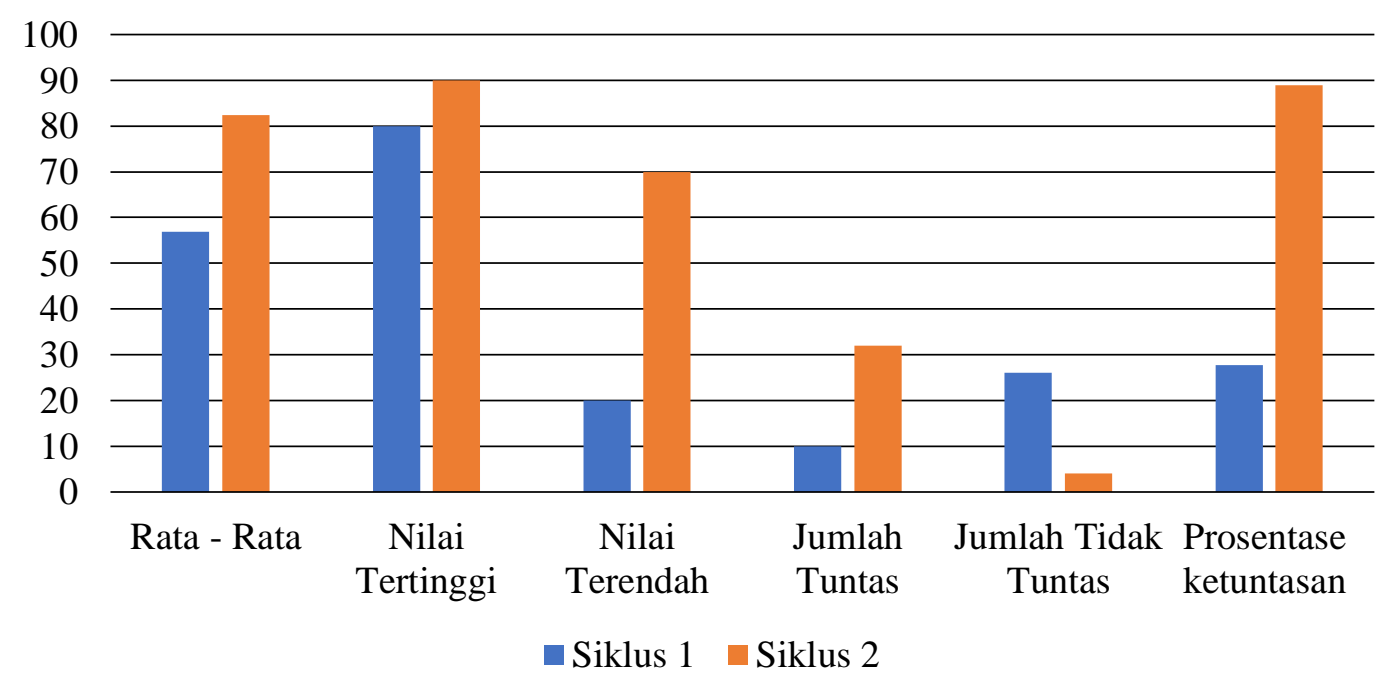

Diagram 3 Prosentase Hasil Belajar Peserta Didik 
Berdasarkan hasil penelitian yang telah dilaksanakan, ketuntasan dari penilaian tes hasil belajar peserta didik pada siklus 1 menunjukkan nilai rata-rata kelas yaitu 57 dengan peserta didik yang tuntas yaitu sebanyak 10 Orang dari 36 jumlah peserta didik kelas X TKJ sehingga prosentase yang diperoleh sebesar $28 \%$, karena peserta didik kurang aktif dalam pembelajaran sehinga nilai yang diperoleh peserta didik masih banyak yang belum mencapai KKM yaitu 80. Pada perbaikan siklus 2 peserta didik mulai terbiasa dengan penilaian unjuk kerja menggunakan perangkat lunak LCD sehingga hasil belajar peserta didik meningkat. Terlihat dari kenaikan nilai rata-rata kelas pada siklus 2 yaitu 82 yang sudah mencapai KKM dengan peserta didik yang tuntas yaitu 32 orang dari 36 orang dan jumlah peserta didik yang belum tuntas sebanyak 4 orang. Prosentase dari penilaian tes hasil belajar pada siklus 2 memperoleh $89 \%$.

Pembahasan di atas menunjukkan bahwa pembelajaran dengan menggunakan perangkat lunak LCD dapat meningkatkan keterampilan hasil belajar peserta didik dan dapat mencapai kriteria ketuntasan minimal dalam mata pelajaran system computer pada materi gerbang logika di kelas X TKJ SMKN 1 Ketapang.

Gerbang logika adalah rangkaian dasar yang membentuk komputer. Jutaan transistor dalam mikroprosesor membentuk ribuan gerbang logika. Gerbang logika merupakan suatu entitas di dalan elektronika dan matematika Boolean. Entitas gerbang logika digunakan di dalam elektronika digital. Sebuah gerbang logika sederhana mempunyai satu terminal output dan satu atau lebih terminal input. Keluarannya berupa nilai logika yang dapat bernilai tinggi (logika 1) atau rendah (logika 0), bergantung level digital atau masukan logika yang diberikan pada terminal input (Budihato, 2004).

Real practicum about logic circuits is not easy, it requires many devices to calculate a complex function. This is made easier with a simulator, such as Logisim (Burch, 2002).

\section{KESIMPULAN}

Berdasarkan pembahasan permasalahan yang telah diungkapkan sebelumnya maka dapat di ambil kesimpulan bahwa:

1. Penggunaan perangkat lunak LCD dalam praktikum sistem komputer pada materi gerbang logika kelas X TKj SMKN 1 Ketapang harusnya melakukan pemasangan yang benar di pc atau laptop.

2. Perangkat lunak LCD terbukti dapatmeningkatkan keterampilan praktikum peserta didik. Hal ini dapat dilihat dari lembar observasi penilaian unjuk kerja peserta didik yang mengalami peningkatan setiap siklusnya. Pada siklus 1 mendapatkan prosentase sebesar $28 \%$ sedangkan ada siklus 2 mendapatkan prosentase sebesar $89 \%$.

\section{DAFTAR PUSTAKA}

Asyhar, Rayandra H. (2011). Kreatif Mengembangkan Media Pembelajaran. Jakarta: Gaung Persada (GP) Press.

Budiharto, Widodo. (2004). Interfacing Komputer dan Mikrokontroler. Jakarta: PT Gramedia.

Burch, C. (2002). Logisim: A Graphical System for Logic Circuit Design and Simulation. ACM Journal on Educational Resources in Computing, 2(1), 5-16. https://doi.org/10.1145/545197.54519 9

Sumantri \& Permana. (2001). Strategi Belajar Mengajar. Bandung: CV. Maulana. 